\title{
РОЛЬ МЕДИЧНОЇ СЕСТРИ В ПРОФІЛАКТИЦІ УСКЛАДНЕНЬ ІШЕМІЧНОГО ІНСУЛЬТУ
}

\author{
О. В. Майборода ${ }^{1}$, О. Л. Сидоренко ${ }^{2}$ \\ ${ }^{1}$ КЗ «Запорізька иентральна районна лікарня» \\ ${ }^{2}$ ДВНЗ «Тернопільський державний медичний університет \\ імені І. Я. Горбачевського МОЗ Украӥни»
}

У статті висвітлено роль медичної сестри у наданні допомоги хворим, які перенесли інсульт. Розглянуто основні моменти, на які необхідно звертати увагу при наданні допомоги для профілактики ускладнень мозкового інсульту.

\section{ROLE OF A NURSE IN PREVENTION OF ISCHEMIC STROKE COMPLICATIONS}

\author{
O. V. Maiboroda ${ }^{1}$, O. L. Sydorenko ${ }^{2}$ \\ ${ }^{1}$ Zaporizhzhia Central District Hospital \\ ${ }^{2}$ I. Horbachevsky Ternopil State Medical University
}

The article examines the role of a nurse in helping the stroke sufferers and describes the main points to be addressed within providing assistance in prevention of cerebral stroke complications.

Вступ. Мозковий інсульт належить до найтяжчих форм цереброваскулярнихзахворювань ізалишається основною проблемою охорони здоров'я в світі. За даними Всесвітньої організації охорони здоров'я (ВООЗ), щороку реєструють 17,3 млн випадків інсульту в усьому світі, з них 100-120 тис. випадків захворювання в Україні [2]. За показниками смертності від інсульту в 2016 р. Україна посіла 41 місце у світі [1].

Інсульт залишається провідною причиною інвалідизації населення у світі. Близько 20 тис. хворих у нашій країні щорічно стають інвалідами внаслідок цієї патології [2]. Згідно з даними Американської асоціації інсульту (American Stroke Association), 30 \% хворих помирає протягом року, 20 \% осіб, які вижили, потребують постійного стороннього догляду, і лише третина хворих після інсульту повертаються до повноцінного життя [2, 3].

Основна частина. Своєчасне лікування інсульту $\epsilon$ життєво важливим для хворого, оскільки невідкладна допомога протягом 3 год після перших симптомів, як правило, істотно знижує рівень інвалідизації пацієнта [4].

Здійснення сестринського догляду за хворим на інсульт є безперервним 24-годинним процесом протягом усього маршруту пацієнта і потребує постійної медсестринської оцінки потреб хворого в отриманні допомоги, оцінки ризику виникнення ускладнень.

(с) О. В. Майборода, О. Л. Сидоренко, 2018
Медичні сестри, які здійснюють догляд за пацієнтами з інсультом, повинні володіти знаннями, мати клінічні навички, впевненість і зацікавленість в наданні ефективної допомоги та реабілітації. Вони потребують освіти, тренінгів і практики в наданні допомоги хворим на інсульт [5].

Рухова реабілітація, розпочата в максимально ранні строки (як тільки буде досягнуто стабілізації основних вітальних функцій - гемодинаміки, дихання), має позитивний вплив на відновлення функцій і зменшує кількість пацієнтів, які залишаються залежними після інсульту. Інтенсивність реабілітаційної програми залежить від стану пацієнта і ступеня його інвалідизації. Якщо активна реабілітація неможлива (наприклад, через пригнічення свідомості), для зменшення ризику розвитку контрактур, болю у суглобах, пролежнів і пневмонії повинна проводитися пасивна реабілітація [6].

Рання мобілізація пацієнтів після інсульту запобігає розвитку таких ускладнень, як аспіраційна пневмонія, тромбози глибоких вен, тромбоемболія легеневих артерій, пролежні.

Відносними протипоказаннями до мобілізації пацієнта з ішемічним інсультом визначено:

1) нестабільний стан серцевої діяльності чи функції інших органів; 
2) систолічний артеріальний тиск <110 або $>220$ мм рт. ст;

3) сатурація кисню <92 \%;

4) частота серцевих скорочень у стані спокою $<40$ або >110 уд./хв;

5) температура тіла $>38,5^{\circ} \mathrm{C}[7]$.

Особлива увага надається питанням оцінки функції ковтання, харчування хворих, правильного їх розташування в ліжку і в кріслі, ранньої активізації, запобігання розвитку пролежнів, контролю больового синдрому, порушення функції тазових органів, ведення пацієнтів із мовними порушеннями. Медичні сестри навчають родичів догляду за хворим, вирішують конкретні проблеми, пов'язані зі захворюванням і труднощами спілкування, допомагають подолати психологічні проблеми.

Однією з основних причин смертності при інсульті (15-20 \%) є таке грізне ускладнення, як аспіраційна пневмонія (АП) [8]. Більшість випадків АП пов'язані 3 невиявленими або некорегованими випадками порушення ковтання (дисфагією) [8]. Заходи, які проводить медична сестра щодо профілактики АП, включають [6]:

1) забезпечення прохідності верхніх дихальних шляхів;

2) санація ротової порожнини і верхніх дихальних шляхів щогодини;

3) запобігання аспірації - визначення можливості безпечного ковтання рідини і їжі хворим; скринінгове тестування функції ковтання;

4) часта зміна положення і правильне позиціонування хворих: ведення їх переважно в положенні лежачи на хворому і здоровому боці з використанням подушок, що підтримують спину, верхню ногу і паретичну руку, але не на спині. Положення лежачи на спині погіршує можливості легеневої вентиляції, санації бронхіального дерева, спричиняє аспірацію слини. Якщо немає протипоказань, пацієнта потрібно укладати на піднесене узголів'я кілька разів на день і годувати тільки в цьому положенні [6].

Другим за частотою ускладненням є пролежні [3, 6]. Усі медичні працівники, які здійснюють догляд за пацієнтами з інсультом, повинні розрізняти пролежні та інші види ран (венозні, артеріальні чи нейропатичні виразки, розриви шкіри, інтертриго), використовувати класифікацію пролежнів різної локалізації, вміти оцінювати ризик пролежнів (за шкалою Браден) та документувати результати оцінювань [8].

Існують фактори, які можуть суттєво впливати на ризик пролежнів, тому важливо під час оцінювання ризику варто звернути увагу на:
1) нутритивний стан (рівень гемоглобіну та преальбуміну, харчування, маса тіла);

2) кровообіг у тканинах (цукровий діабет, нестабільність гемодинаміки, низький артеріальний тиск погіршують мікроциркуляцію та оксигенацію);

3) зволоженість шкіри (сухість та надмірна вологість збільшують ризик пролежнів);

4) тяжкість стану, супутні захворювання, похилий вік;

5) порушення чутливості та температури тіла.

Шкіра пацієнта потребує постійного ретельного догляду:

1. Обов'язковий щоденний туалет всій поверхні шкіри («купання в ліжку» - почергове обтирання губкою всіх частин тіла).

2. Застосування підгузків підвищує ризик розвитку пролежнів, тому особам з високим і дуже високим ризиком розвитку пролежнів та з порушенням сечовипускання (за типом нетримання) показана катетеризація сечового міхура (катетером Фолея).

3. Не бажане застосування масажу для профілактики пролежнів, а також слід уникати сильного тертя шкіри, яке може викликати мікротравми та/або запалення.

4. Суха шкіра $є$ фактором ризику розвитку пролежнів. Слід уникати протирання шкіри спиртовими розчинами, які містять камфору, діамантовий зелений, борну кислоту тощо, бо вони роблять шкіру сухою.

5. Для пом'якшення та зволоження шкіри необхідно використовувати спеціальні засоби: олії, креми, лосьйони.

6. Важливо уникати надмірного зволоження та перегріву ділянок шкіри, оскільки ці чинники погіршують захисні властивості рогового шару.

Положення тіла пацієнта у ліжку:

1) необхідно уникати перебування пацієнта у положенні, при якому є прямий тиск на пролежні;

2) для пацієнтів із високим ризиком розвитку пролежнів для зменшення тиску на найвразливіші ділянки шкіри необхідно використовувати протипролежневі матраци;

3) для кожного пацієнта з підвищеним ризиком пролежнів потрібно розробити графік зміни положення тіла. Частоту зміни положень тіла пацієнта встановлюють відповідно до ступеня ризику розвитку пролежнів: для осіб із високим ризиком розвитку пролежнів - кожні 2 год вдень і 3,5 год вночі, осіб із дуже високим ризиком слід повертати кожні 1-2 год на 30-45, укладаючи на один чи другий бік, спину або живіт (якщо немає протипоказань);

4) необхідно уникати стискання, тертя та зсуву шкіри під час зміни положення тіла, використовувати допоміжні засоби; 
5) уникати положень, у яких виникає значний тиск на вразливі ділянки тіла, зокрема на боці під кутом 90 або напівсидячи;

6) коли пацієнт сидить, слід обирати зручне положення, яке не обмежує рухів та зменшує тиск на м'які тканини;

7) потрібно використовувати підставку для ніг, якщо ноги пацієнта не торкаються землі при сидінні;

8) необхідно збільшувати обсяг рухів та мобільність, наскільки це можливо.

Порушення ковтання (дисфагія) як ускладнення інсульту.

Дисфагію спостерігають у 64-90 \% пацієнтів 3 інсультом [9]. Може відбуватись порушення однієї чи кількох фаз ковтання: оральної, оральної підготовчої, фарингеальної чи стравохідної. Найчастіше у пацієнтів з інсультом порушується орофарингеальна фаза. Частота дисфагії вища в гострий період інсульту і знижується до $15 \%$ упродовж 3 місяців.

Дисфагія пов'язана з виникненням таких ускладнень, як аспіраційна пневмонія, дегідратація та недостатнє харчування. Аспірація виникає у 22-42 \% пацієнтів відповідно до відеофлюороскопічного дослідження. Необхідно пам'ятати, що у 1/3-1/2 пацієнтів після інсульту з тих, хто може мати аспіраційний синдром, має приховану аспірацію (пацієнти не мають таких ознак аспірації, як кашель, поява «вологого» голосу тощо після ковтання). Наявність аспірації підвищує ризик виникнення аспіраційної пневмонії. Недоїдання виявляють у 7-15\% пацієнтів при прийманні у лікарню та в 22-35 \% пацієнтів на 2 тижні госпіталізації. Серед пацієнтів, які потребують тривалої реабілітації, відсоток осіб із недостатнім харчуванням може сягати 50 \%. Для запобігання виникненню вторинних ускладнень дисфагії важливо обстежувати кожного пацієнта з гострим інсультом на наявність порушень ковтання, а за умови їх виявлення - провести подальшу повну оцінку [9].

Обов'язкові дії медичного персоналу для попередження ускладнень дисфагії:

1. Пацієнт з інсультом не повинен їсти, пити та приймати через рот ліки (нічого через рот), доки не буде встановлено, що ковтання $\epsilon$ безпечним.

2. Тест на порушення функції ковтання виконує медична сестра при госпіталізації хворого. Скринінг дисфагії проводять біля ліжка пацієнта. Він полягає в оцінці рівня свідомості пацієнта і його здатності взяти участь в обстеженні, оцінці ступеня постурального контролю (пацієнт здатний сидіти у вертикальному положенні - за підтримки чи самостійно).
Порушення свідомості й постурального контролю унеможливлюють подальший скринінг, пацієнта необхідно годувати парентерально до наступного скринінгу.

Якщо пацієнт здатний активно брати участь в обстеженні й може за підтримки сидіти у вертикальному положенні, процедура також має включати:

1) спостереження за гігієною ротової порожнини, контроль слиновиділення;

2) спостереження за проявами порушень ротоглоткової фази ковтання (задуха, кашель, «вологий» голос тощо);

3) оцінка якості голосу пацієнта, функції м'язів ротової порожнини, чутливості ротової порожнини та початкових відділів глотки, а також здатність кашляти;

4) за необхідності (для перевірки аспіраційного ризику) проводять тести з водою для перевірки функції ковтання - тест із 3 чайними ложками води. Пацієнту пропонують випити по черзі 3 чайні ложки води і після кожної випитої ложки спостерігають за появою ознак аспірації (кашель, зміна звучання голосу тощо). Якщо ознаки аспірації не з'явились - пропонують випити воду із склянки, далі - спробувати проковтнути їжу різної текстури.

3. Усім пацієнтам, у тому числі й тим, хто успішно пройшов скринінг дисфагії, необхідно щоденно проводити моніторинг порушень ковтання впродовж усього періоду госпіталізації, оскільки порушення ковтання може розвинутися у відтермінований період.

4. За результатами скринінгу лікар або дозволяє приймати їжу через рот, або визначає інші способи харчування пацієнта. Пацієнтам із порушенням ковтання рекомендоване раннє встановлення назогастрального зонда (впродовж перших 48 год із моменту виникнення інсульту) [8].

Біль у плечі - досить часте ускладнення у реабілітаційний період у пацієнтів з інсультом. Причиною розвитку больового синдрому вважають розтягнення сухожильної капсули навколо головки плечової кістки, слабкість якої розвивається внаслідок відсутності тонусу та рухової активності м'язів плеча та верхньої кінцівки.

Для профілактики виникнення підвивиху плечового суглоба паралізованої верхньої кінцівки та розвитку синдрому «больового плеча» у пацієнтів з інсультом на ранніх етапах реабілітації рекомендовано використання бандажа-фіксатора плечового суглоба при вертикальному положенні пацієнта (стоячи, сидячи).

Оцінку больового синдрому проводять із використанням 10-бальної шкали болю чи візуально-аналогової шкали. 
При болях у плечовому суглобі необхідно проведення аступних дій медичними працівниками:

1. Ретельне позиціонування хворих (рис. 1) - виведення лопатки в положення протракції (вперед) при розташуванні хворого на хворому боці, підтримка паретичної руки подушкою в положенні лежачи на здоровому боці, підтримка плечового суглоба подушкою (в положенні лежачи на спині) [6].
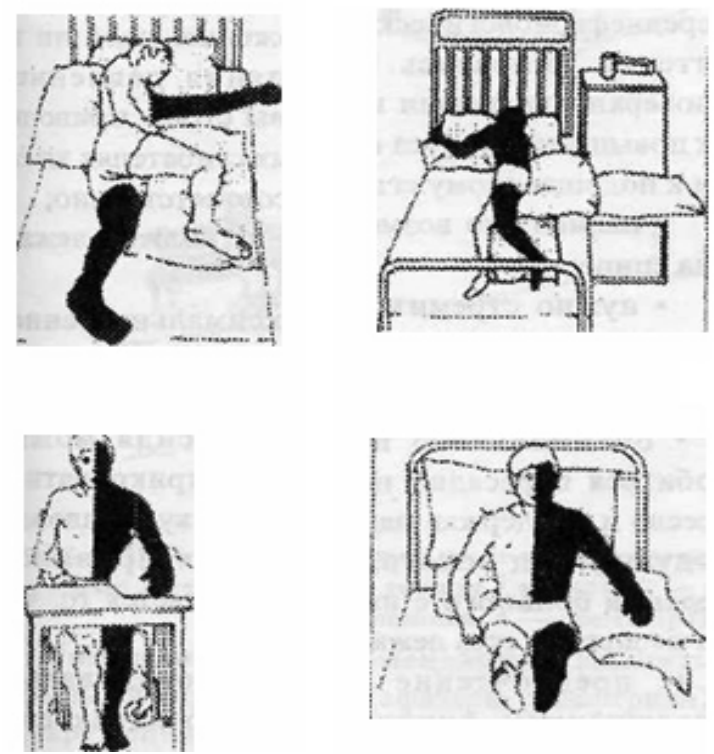

Рис. 1. Типова схема перевірки правильного позиціонування пацієнта.

\section{СПИСОК ЛІТЕРАТУРИ}

1. Стасенко Т. Інсульт: впровадження успішних стратегій лікування [Електронний ресурс] / Т. Стасенко // Український медичний часопис. - 2017. - Режим доступу до ресурсу : http://www.umj.com.ua/article/117650/insultvprovadzhennya-uspishnih-strategij-likuvannya.

2. Ішемічний інсульт : Уніфікований клінічний протокол медичної допомоги. - К., 2012. - С. 9.

3. Guidelines for the Primary Prevention of Stroke. A Guideline for Healthcare Professionals from the American Heart Association/American Stroke Association // Stroke - CШA, 2011. - C. 518. - Mode access : http://stroke.ahajournals. org/content/strokeaha/42/2/517.full.pdf.

4. Stroke and Stroke Rehabilitation. American Academy of Neurology Institute. - CШA, 2017. - C. 7. - Mode access : https://www.aan.com/siteassets/home-page/policy-andguidelines/quality/quality-measures/15strokeandrehabme asureset_pg.pdf.

5. Реабілітація, профілактика і лікування ускладнень та планування виписки при ішемічному інсульті : адап-
2. Раннє застосування пасивних рухів у паретичній руці та в плечі у межах фізіологічної амплітуди руху з дотриманням паттерна природного руху [7].

Таким чином, медсестринський процес при здійсненні догляду за пацієнтом із гострою цереброваскулярною патологією відрізняє великий об'єм його потреб, які постійно змінюються та потребують моніторингу та оцінки в процесі надання допомоги. Необхідність регулярного спостереження за такими показниками, як дихання, ковтання, стан харчування, здатність регулювати екскреторні функції і стан шкіри; великий обсяг залежних і незалежних медсестринських втручань, активний контакт і взаємодія з пацієнтом і сім'єю вимагає від медичної сестри постійного професійного вдосконалення.

Висновки. Складність медсестринського процесу при наданні допомоги хворому з інсультом, можливість швидкої зміни стану пацієнта, великий обсяг залежних та незалежних сестринських втручань вимагає від медичної сестри професійного підходу, постійного вдосконалення клінічних та практичних навичок. Проведення тренінгів, навчання і практики в наданні допомоги хворим із гострою цереброваскулярною патологією - запорука надання належної висококваліфікованої медсестринської допомоги та зниження ризику виникнення ускладнень інсульту.

тована клінічна настанова, заснована на доказах. - К., 2012. - C. 102-110.

6. Хабіров Ф. Рання реабілітація хворих, які перенесли мозковий інсульт, в системі мультидисциплінарних бригад [Електронний ресурс] // Медична практика. - 2009. Режим доступу до ресурсу : http://mfvt.ru/rannyayareabilitaciya-bolnyx-perenesshix-mozgovoj-insult-v-sistememultidisniplinarnyx-brigad/.

7. Устінов О. Реабілітація після ішемічного інсульту [Електронний ресурс] / О. Устінов // Український медичний часопис. - 2015. - Режим доступу до ресурсу : http://www.umj.com.ua/article/90478/ishemichnij-insultmedichna-reabilitaciya.

8. Гострі порушення мозкового кровообігу. Ішемічний інсульт : Уніфікований клінічний протокол медичної допомоги. - К., 2012. - С. 34-45.

9. Сучасні принципи діагностики та лікування хворих із гострим ішемічним інсультом та TIA : адаптована клінічна настанова, заснована на доказах. - К., 2012. - С. 85. 